\title{
Comparison of The Implementation of Direct Instruction, Problem-Based Instruction, and Cooperative Learning using Cabri 3D on Geometry
}

\author{
Firmansyah $^{1}$, E Gradini ${ }^{2}$, B Yustinanningrum ${ }^{3}$, and NA Lubis ${ }^{4}$ \\ \{egagradini, firmansyahb, bettryyustinanningrum, nurainunlubis\}@stain-gp.ac.id \} \\ Mathematics Education Departement, STAIN Gajah Putih Takengon, Jalan Yos Sudarso no. 10 \\ Takengon, Indonesia ${ }^{1,2,3,4}$
}

\begin{abstract}
This study aims to compare the implementation of 3 teaching strategies; Direct Instruction, Cooperative Learning, and Problem Based Instruction in the geometry classroom. Cabri 3D was used as media to teach geometry in a classroom where 38 students participated as the subject in this study. The instructions were implemented for 8 meetings to evaluate the practicality of Cabri 3D in Direct Instruction, Cooperative Learning, and Problem Based Instruction. The result indicates that each instruction has their own advantages but generally, Problem Based Instruction is the best teaching strategies to conduct geometry class. The practicality based on the average score of implementation in Direct Instruction is 2.47 (good), Cooperative Learning is 2.54 (very good), and Problem Based Instruction is 2.49 (good). Teacher activities in all of the three learning instructions are in a good category, Direct Instruction is 3.67 (good), Cooperative Learning is 3.82 (good), and Problem-Based is 3.99 (good). This finding supports the theories in using Cabri 3D as teaching media in mathematics classroom.
\end{abstract}

Keywords: Cabri 3D, Teaching Media, Direct Instruction, Problem Based Instruction, Cooperative Learning

\section{Introduction}

Geometry is an important way to understand the real world (Gunhan, 2009). Geometry is the most perceivable concepts in daily life. Geometry appears naturally in the structure of the solar system, a geological formation, rocks and crystals, plants and flowers, and even in animals. It is also a major part of the synthetic world such as art, architecture, cars, machines, and virtually everything humans create. In the same vein, studies revealed that geometry is applicable and relevant to employment in everyday life, other subjects in the curriculum such as science, arts, and technology. Also, geometry is used to develop students' spatial awareness, intuition, visualizations and to solve practical problems and so on (Fabiyi, 2017).

According to the National Council of Teacher of Mathematics (NCTM), in geometry classroom; visualization, spatial reasoning, and geometry modelling are used to solve problems given (NCTM, 2012). It is preferably easy for a teacher to use the examples in daily life in order to make students understand the concept. However, many previous studies have shown that understanding geometrical objects or images is still challenging for students. 5 of 7 mathematics-talented students in Korea had difficulty in imagining a 3-dimensional object in a space depicted on a flat plane(Ryu, Yeong, and Seong, 2007). Researchers in Nigeriaand 
Malaysia revealed the factors that are responsible for students' difficulty in learning geometry to include: lack of proof by students, lack of background knowledge, poor reasoning skill in geometry, geometric language comprehension, lack of visualizing abilities, teachers' method of teaching, non-availability of instructional materials, lack of proof by students, gender differences among others (Mason, 2002; Noraini, 2006; Uduosoro, 2011; Telima, 2011, and Aysen, 2012).Adegun and Adegun (2013) stated that students generally encountered difficulties in geometry and performed poorly in senior secondary school mathematics lesson. Also, Telima (2011) found out that many students fail to grasp key concepts in geometry and leave mathematics classes without learning the basic terminology. Findings have shown that some factors are identified to make the learning of geometry concepts in mathematics difficult which include: teachers' methods of instruction, geometric language, visualizing abilities (Noraini, 2006 and Aysen, 2012). Other factors include: non-availability and obsolescence of instructional materials, gender differences, poor reasoning skill, inadequate time, inadequate school curriculum and lack of proof by students (Mason, 2002; Uduosoro, 2011and NERDC, 2012). All these are believed to have a negative effect on the learning of geometry.

Teacher need to implement different teaching strategies to enhance students' understanding in conducting geometry classroom. Direct Instruction, Problem Based Instruction, and Cooperative Learning believed effective to beimplemented as the appropriate technique.

Spatial ability is intended as a skill in representing, transforming, generating, and recalling symbolic, non-linguistic information(Yilmaz, 2009). It divided into three categories, namely: (1) mental rotation; (2) spatial perception; and (3) spatial visualization. Spatial ability is an intelligence factor that is not only important for mathematics and science, but also for success in many professions. Like activities in the engineering world, aviation, shipping, geography, astronomy, industrial technology and so on. Because of the importance of this spatial ability, teachers must pay more attention to developing it. In Geometry teaching activities, teachers have implemented various types of learning models such as Direct Instruction, Cooperative Learning, and Problem Based Instruction. The three learning models have their advantages in teaching spatial abilities to students.

This study aims to compare the implementation of 3 teaching strategies; Direct Instruction, Cooperative Learning, and Problem Based Instruction in the geometry classroom. Teaching skills, students' activities, and the effectiveness of each teaching strategy in every strategy was determined and compared. The instructions were conducted using Cabri3D as educational tools. This software helps to explore the geometry of space so that users easily construct geometric structures in the three-dimensional space, and explore the structures constructed. Thus Cabri 3D can open up opportunities for students to improve their spatial abilities and build their geometric knowledge after observing, exploring, experimenting and hypothesizing further on that formal proof can eventually be applied in solving geometry problems. 


\section{Literature Review}

\subsection{Direct Instruction}

The Direct Instruction model is a learning model that requires teachers to provide background information, demonstrate the skills being taught and then provide time for students to practice these skills and receive feedback about what they are doing (Nur, 2004). Joyce and Weil stated that the Direct Instruction is a learning model consisting of teachers explaining concepts or skills to students then they are tested for understanding through direct training by the teacher and instructing them to continue training under the guidance of the teacher or guided training (Joyce and Weil, 2000). It can be concluded that the direct Instruction is a learning model that starts from giving information from the teacher to students, demonstrating the teacher's skills and then giving the skills training as well as providing time for students to exercise independently under the guidance of the teacher.

There are 5 steps in Direct Instruction in which the model is still teacher-centred, which are: (1) Preparatory phase (Conveying the learning objectives and motivating students), (2) Demonstrations (Explain and demonstrate a specific learning strategy), (3) Guided training; Provide opportunities for guided training, (4) Feedback (Understanding checking and feedback providing. Stop the exercise and check to find out what kinds of problems students face regarding the strategy), (5) Advanced Training: Provide independent training and apply different situations (Nur, 2004).

\subsection{Problem-Based Instruction}

According to Pierce and Jones, when implementing problem-based Instruction, the teacher needs to: (1)preparing students to act as problem solvers by working together, (2) inquiry and investigation, namely exploring and distributing information, (3) performance that presents findings, (4) the question and answer purposes is to examine the accuracy of the solution, (5) reflection on problem-solving (Rusman, 2012). Problem-based instruction has a learning scheme; presenting the problem, problem analyzing, discovery and reporting, solution presentation and reflection, overview, integration and evaluation (concluding, integrating and evaluating) (Tan, 2004).

The advantages of Problem-based Instruction are: (1) problem-solving phase is effective incontents understanding; (2) problem-solving able to challenge students' abilities and providing satisfaction to students; (3) Problem-based Instruction can improve learning activities; (4) helping the student transfer knowledge to understand problems in daily life; (5) helping students develop their knowledge and to be responsible for their own learning; (6) helping students to understand the nature of learning as a way of thinking not only to understand the concepts based on textbooks; (7) Creates a fun learning environment, and (8)Stimulating students to study continuously (wina, 2008).

\subsection{Cooperative Learning}

According to Johnson, the cooperative learning model is one of contextual learning. Cooperative learning can be defined as a structured work or a group learning system. It is 
emphasizes shared attitudes or behaviours in a regular working group, consisting of two or more people (Amri and Ahmadi, 2010). Cooperative Learning conducted in 6 phases; (1) Conveying goals and preparation, (2)presenting information, (3)organizing students into groups, (4)coaching group, (5)evaluating, (6)Giving recognition or appreciation (Suprijono, 2009)

\subsection{Cabri 3D}

Cabri technology was born in 1985 at a research laboratory of France's Center National de la RechercheScientifique and Joseph Fourier University in Gronoble, Cabri 3D is one of the most interactive geometry software. Firstly introduced at the CABRILOG conference in Rome in September 2004 (Rososzczuk, 2015).

Cabri 3D is a software specifically developed by educators, mathematicians to help the geometry learning process (Cabri, 2012). Cabri can open opportunities for students to construct their geometry knowledge after observing, exploring, experimenting and hypothesizing further on that formal verification can eventually be applied in solving geometry problems (Sabandar, 2002).

\section{Research Method}

The geometry instructionwas conducted by applying geometry learning using Cabri 3D on 3 different teaching strategies. The three teaching strategies are Direct Instruction, Cooperative Learning, and Problem Based Instruction. This was a trial phase of Developmental Research to develop Cabri 3D-based teaching media on geometry.

The trial was implemented in $10^{\text {th }}$ Grade students. Direct Instruction was implemented for 3 meetings (1st, 3rd, 6th meeting), Cooperative Learning was implemented for 3 meetings (2nd, 4th, 7th meeting), and Problem Based Instruction was implemented for 2 meetings (5th, 8th meeting).

The practicality of teaching media refers to the implementation of teaching in the classroom. The score of teaching implementation is obtained from observations during instruction. It consists of learning components and supporting elements.

Learning components include syntax, social systems and reaction principles. This component is part of the learning instruction component according to Joyce and Weil (2003). Those components are (1) syntax, (2) social system, (3) principles of reaction, (4) the support system, and (5) instructional effect and nurturant effect component. The Supporting elements include learning tools and information technology devices.

In addition to implementation of learning, observers also make observation on the teacher's activities on learning. The Teacher's activities in learning include all phases in each teaching strategies.

According toArends (2012), the phase of direct instruction includes clarify goals and establish set, demonstrate knowledge or skill, provide guided practice, check for understanding and provide feedback, provide extended practice and transfer. The phase of cooperative learning includes clarify goals and establish set, present information, organize students into learning teams, assist teamwork and study, test on the materials, provide recognition. The phase of Problem-Based Instruction includes orient students to the problem, 
organize students for study, assist independent and group investigation, develop and present artefacts and exhibits, analyze and evaluate the problem-solving process.

The data analysis using average on descriptive statistic. The average obtained on each aspect of the observation as shown on table 1

Table 1: Learning implementation category

\begin{tabular}{|c|c|}
\hline Interval & Category \\
\hline $2,5 \leq I \leq 3,0$ & Very Good \\
\hline $1,5 \leq I<2,5$ & Good \\
\hline $0,5 \leq I<1,5$ & Fair \\
\hline $0 \leq I<0,5$ & Poor \\
\hline
\end{tabular}

The average which is obtained in each aspect of observation of the teacher's activities on learning is categorized as shown on table 2

Table 2: Teacher's activities on learning category

\begin{tabular}{|c|c|}
\hline Interval & Category \\
\hline$T A \geq 4,5$ & Very Good \\
\hline $3,5 \leq T A<4,5$ & Good \\
\hline $2,5 \leq T A<3,5$ & Satisfactory \\
\hline $1,5 \leq T A<2,5$ & Fair \\
\hline$T A<1,5$ & Poor \\
\hline
\end{tabular}

The observation results of the implementation of learning were compared descriptively to the three learning instruction. Furthermore, it was confirmed by the results of observations of the teacher activities in each learning model.

\section{Results}

\subsection{Implementation Of Learning}

The result from the implementation of learning geometry using media based on cabri 3D can be seen in Figures below

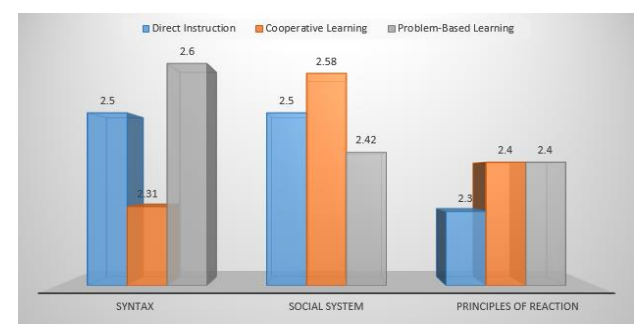

Figure 1: Graph of Implementation of the Learning Component 
All learning components observed were in the "good" and "very good" category for each teaching strategies. In the syntax component, the lowest score is on cooperative learning, which is 2.31 (good). The score of observation on "provide recognition" phase is 1.83 . In the social system component, the lowest score is onproblem-based learning, which is 2.42 (good). The result of the aspect "interaction between students and teachers" is 2.00 . In the principles of reaction component, the lowest score on direct learning is 2.30 (good). The result of the aspect "teacher give strength to students" is 2.00 .

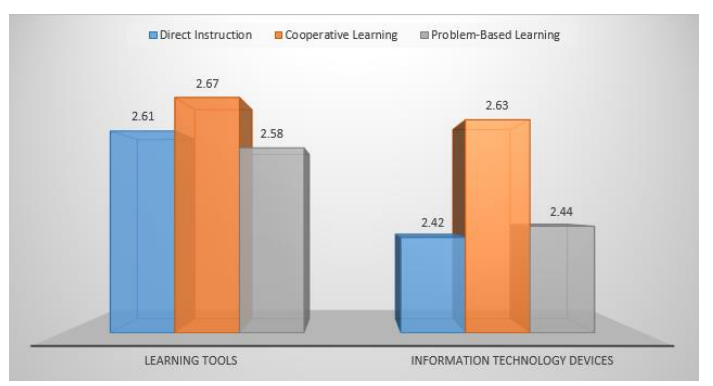

Figure 2: Graph of Implementation of Learning Support Elements

All component of learning supporting elements observed are in the "good" and "very good" category. In the aspect of "learning tools", the lowest score on problem-based Instruction is 2.58 (very good) and the highest in cooperative learning is 2.67 (very good). In the aspect of "information technology device", the lowest observation score on direct learning is 2.42 (good) and the highest in cooperative learning is 2.63 (very good).

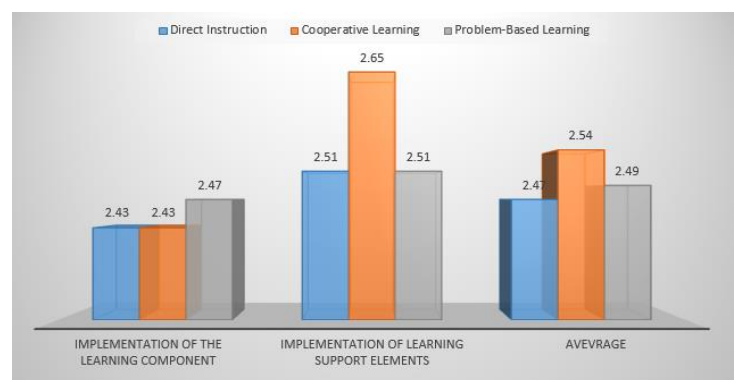

Figure 3: Graph of Implementation of Learning

Overall, the implementation of learning using cabri3D-based media in cooperative learning is best. The average results of observations on cooperative learning is 2.54 (very good), problem-based Instruction is 2.49 (good), and direct learning is 2.47 (good).

\subsection{Teacher's Activities}

The result from the teacher's activity on learning geometry using media based on cabri3D can be seen in Figures 4. 


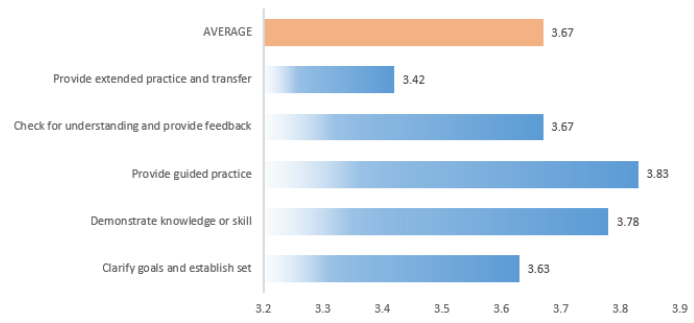

Figure 4: Graph of Teacher's Activities on Direct Instruction

The average score of observing teacher activity in direct learning is 3.67 (good). The highest activity in the phase of "provide guided practice" is 3.84 and the lowest is in the phase of "provide extended practice and transfer" is 3.42 .

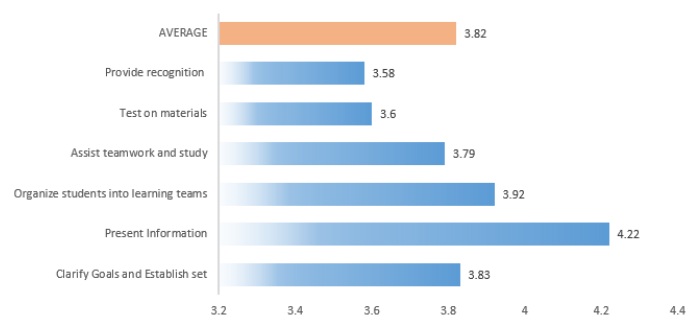

Figure 5: Graph of Teacher's Activities on Cooperative Learning

The average observation of teacher activity in cooperative learning is 3.82 (good). The highest activity in the phase of "present information" is 4.22 and the lowest in the phase of "provide recognition" is 3.58 .

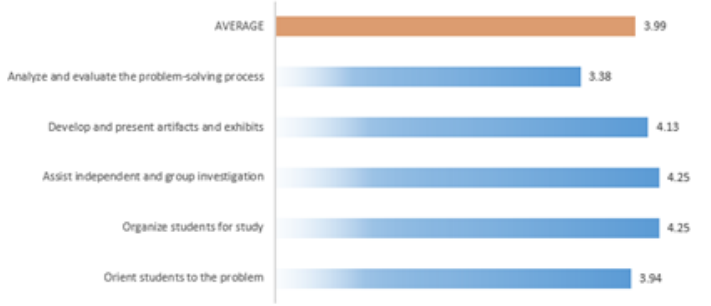

Figure 6: Graph of Teacher's Activities on Problem-Based Learning

The average score of observing teacher activity on Problem Based Instruction is 3.99 (good). The highest activity in the phase of "assist independent group investigation" and "organize students for study" is 4.25 and the lowest in the phase of "analyze and evaluate the problem-solving process" is 3.58 .

The observation score of teacher activities on the three teaching strategies are in the good category. Teacher activity score in Problem-Based Instruction 3.99 (good) is higher than teacher activity in Cooperative Learning 3.82 (good) and Direct Instruction is 3.67 (good). This is consistent with observations of implementation of learning (Figure 3) on the aspect 
"implementation of the learning component", where Problem-Based Instruction shows the best result.

\section{Conclusions}

The Geometry instruction using Cabri 3D-based teaching media fulfil the practicality criteria of teaching media. This can be seen from the implementation of learning in the three teaching strategies in the "good" and "very good" category.

Each strategies has their own advantage in its implementation, but based on observation, generally the implementation of Cooperative Learning is the best. The average score of learning implementation in Cooperative Learning is 2.54 (very good), Problem-Based Instruction is 2.49 (good), and Direct Instruction is 2.47 (good).

The result of observation of teacher activities in all three teaching strategies are in the good category. But the result of observation of teacher activities on Problem-Based Instruction (3.99) is higher than Cooperative Learning (3.82) and Direct Instruction (3.67). These results are consistent with the implementation of learning on aspect "implementation of the learning component" where Problem-Based Instruction is better than others

\section{.References}

[1]Adegun, I.K, and Adegun, B.O., 2013. Students and Teachers' Views of Difficult Areas in Mathematics Syllabus: Basic Requirement for Science And Engineering Education. Journal of Education and Practice, 4(12), 2013, 235-243.

[2]Aysen,O. 2012. Misconceptions in Geometry And Suggested Solutions For Seventh Grade Students. International Journal of New Trends inArts, Sports and Science Education, 1(4), 1 13.

[3]Arends, R.I., 2012. Learning to Teach, the McGraw-Hill Companies. New York, $9^{\text {th }}$ edition.

[4]Cabri, 2012. Cabri Strengths. Retrieved from http://www.cabri.com/educativesoftware.html diakses 12 Desember 2012 jam 20.15

[5]Gunhan, B., Turgut, M., Yilmaz, 2009. Spatial Ability of a Mathematics Teacher: The Case of Oya. (Online), IBSU Scientific Journal 2009, 3(1). (http://www.journal.ibsu.edu.ge, diakses 5 Oktober 2012).

[6]Joyce, Bruce, and Marsha, Weil.,2003. Models of Teaching, Prentice-Hall of India Private Limited.New Delhi, $5^{\text {th }}$ edition.

[7]Mason, M. 2002.The van Hiele levels of geometric understanding. Retrieved fromhttp:/jwilson.coe.uga.edu/EMAT8990/GEOMETRY.

[8]Mangun, S., W, 2013. Pembelajaran Berbasis Riset, Jakarta: Akademia Permata.

[9]Nafiah, Y.,N, dan Suyanto, W. Penerapan Model Problem-Based Learning untuk Meningkatkan Keterampilan Berpikir Kritis dan Hasil Belajar Siswa, Jurnal Pendidikan Vokasi, Vol 4, Nomor 1, Februari 2014

[10]Noraini, I.2006. Teaching and Learning Of Mathematics: Making Sense and Developing Cognitive Abilities.Perak: Utusan Publication Sdn.Bhd. Nigeria.

[11]NCTM. 2012. Geometry Standard for Grades 9-12. retrieved from http://www.nctm.org/resources/content. aspx?id=12628, accessed on Oktober 5, 2012). 
[12]Nur, M dan Kardi, S., 2004.Strategi-Strategi Belajar, Surabaya : Pusat Sains dan Matematika Sekolah,University Press

[13]Paulina, M. 2007. Perspectives on the Teaching of Geometry for the 21st Century. Dordrecht: Kluwer.

[14]Rososzczuk, R., 2015. Aplication of Cabri 3D in teaching stereometry, Advance in Science and Technology Reseacrh Journal 9:148-151

[15]Rusman, 2012. Model-model pembelajaran mengembangkan profesional guru, Jakarta : Raja Grafindo Persada.

[16]Sabandar, J., 2002. Pembelajaran Geometry dengan Menggunakan Cabry Geometri II, Jurnal Matematika atau Pembelajarannya. ISSN: 0852-7792 Tahun VIII, Edisi Khusus, Juli 2002.

[17]Soedjadi, R., 2000. Kiat Pendidikan Matematika di Indonesia, Jakarta: DIRJEN DIKTI.

[18]Sugandi, A., 2002. Pembelajaran Pemecahan Masalah Matematika Melalui Model Belajar Kooperatif Tope Jigsaw.

[19]Suprijono, A., 2009. Cooperative learning: teori \& aplikasi PAIKEM, in Theory of cooperative learning for application in Indonesia, Bandung: Pustaka Pelajar.

[20]Syahputra, E, 2011. PeningkatanKemampuanSpasialdanDisposisiMatematisSiswa SMP DenganPendekatan PMRI padaPembelajaranGeometriBerbantuanKomputer. Bandung: Program Pascasarjana UPI Bandung.

[21]Tan, O., 2004. Problem-Based Learning innovation : Using Problem to Power Learning in the 21st Century, singapore: Cengage Learning Asia Pte Ltd.

[22]Telima, A. 2013. Problems of Teaching and Learning of Geometry in Secondary Schools in River State, Nigeria.

[23]Toptas, V., Celik, S., and Karaca, E.T.. 2012. Improving $8^{\text {th }}$ Grades Spatial Thinking Abilities Through a $3 d$ Modeling Program. (Online). The Turkish Online Journal of Educational Technology. Volume 11 Issue 2. (http://www.tojet.net/articles/v11i2/11 213.pdf, diakses 5 Oktober 2012).

[24]Uduosoro,U.J.2011. Perceived and Actual Learning Difficulties of Students in Secondary School Mathematics. International Multidisciplinary Journal, Ethiopia, 5 (5), 357-366.

[25]Wina, S., 2008. Strategi pembelajaran, Jakarta: Kencana prenada Media.

[26]Yilmaz, H., B, 2009. On The Development And Measurement Of Spatial Ability, (Online), Volume 1, Issue 2, (http://www.iejee. com/1_2_2009/yilmaz.pdf, diakses 15 Agustus 2012). 